\title{
Diversity and Origin of Indigenous Village Chickens (Gallus gallus) from Chad, Central Africa
}

\author{
Khadidja Hassaballah ${ }^{1}$, Vounparet Zeuh², Raman A. Lawal ${ }^{3}$, Olivier Hanotte ${ }^{3}$, \\ Mbacké Sembene ${ }^{4}$ \\ ${ }^{1}$ Department of Biology, Faculty of Exact and Applied Sciences, University of N'Djamena, N'Djamena, Chad \\ ${ }^{2}$ Livestock Polytechnic Institute of Moussoro, Moussoro, Chad \\ ${ }^{3}$ School of Life Sciences, The University of Nottingham, University Park, Nottingham, UK \\ ${ }^{4}$ Department of Animal Biology, Faculty of Sciences and Techniques, Cheikh Anta Diop University of Dakar, \\ Dakar, Senegal \\ Email: ${ }^{*}$ hassaballaro@yahoo.fr
}

Received 27 August 2015; accepted 21 September 2015; published 24 September 2015

Copyright (C) 2015 by authors and Scientific Research Publishing Inc.

This work is licensed under the Creative Commons Attribution International License (CC BY).

http://creativecommons.org/licenses/by/4.0/

(c) (†) Open Access

\begin{abstract}
In this study we assess the maternal genetic diversity and origin of indigenous village chickens from Chad complementing previous phenotypic and biometric measurements studies. We analysed a $387 \mathrm{bp}$ fragment of the mitochondrial DNA (mtDNA) D-loop region of 181 village chickens from three populations of western Chad (Lake Chad/Hadjer Lamis), central Chad (Guera) and south-west Chad (Pala) and at different poultry markets in N'Djamena. Twenty-five polymorphic sites and 20 haplotypes are identified. Phylogenetic and network analyses group all chicken into a single mtDNA haplogroup $D$. Comparison with reference sequences shows that this haplogroup is the commonest one observed in chicken and it supports the Indian subcontinent as the maternal center of origin for the village chicken in Chad. Little genetic variation was found within and between populations which is in agreement with a recent and a maternal founding effect for the chicken in the country.
\end{abstract}

Keywords

mtDNA, D-Loop, Genetic Variation, Origin, Village Chickens, Chad

${ }^{*}$ Corresponding author.

How to cite this paper: Hassaballah, K., Zeuh, V., Lawal, R.A., Hanotte, O. and Sembene, M. (2015) Diversity and Origin of Indigenous Village Chickens (Gallus gallus) from Chad, Central Africa. Advances in Bioscience and Biotechnology, 6, 592-600. http://dx.doi.org/10.4236/abb.2015.69062 


\section{Introduction}

The domestic chicken is one of the most common and widespread domestic animals species with an estimated population in 2010 of more than 1.6 billion in Africa [1]. It is also the most abundant species of domestic bird in the world [2]. Human keeps chickens primarily as a source of food, consuming both their meat and their eggs. Many authors think that the main maternal ancestor of village chicken is the red jungle fowl Gallus gallus ssp. which was domesticated in South and South-East Asia at least since 5400 BC [3].

The introduction of village chicken in Africa remains relatively little documented [4]. The earliest evidence of chicken on the African continent is from Egypt and it dates from around 2000 BC. Chickens were most likely imported at the time as a curiosity and an addition to exotic menageries. Chicken did not become a regular feature of the Egyptian farmyard before the Ptolemaic period of 304 - 330 BC [5]. The oldest recognizable pictorial evidence of birds was reported by Haller in 1954 [6] and was assumed to have dated from the second half of the fourteenth century BC. In West Africa the earliest evidences are from Mali circa in AD 450 - 850, while archeological evidences show the presence of chicken in Chad in post-1700 AD [7].

Typically, today most African households will keep 5 to 20 indigenous birds essentially for eggs and meat production [8] [9]. However, the initial trigger for the adoption of domestic chickens by African communities, as it has been assumed for the initial domestication of the chicken in Asia, could have been for socio-culture and/ or recreation (e.g. cockfighting) rather than as a new source of food. Today indigenous chickens represent an important valuable animal genetic resource and the conservation, sustainable exploitation and improvement of local breeds are therefore important issues. Many of the populations developed over hundreds of years were selected for morphological and appearance characteristics as much as for production purposes. This is illustrated by the very large numbers of chicken breeds and ecotypes found across the world.

Recent genetic studies have pointed to multiple maternal origins of domestic chicken in Asia [10]. Also, the African continent likely witnessed several major introductions of chickens from different Asian centers of origin including South Asia and islands South East Asia. In East Africa two distinct major mtDNA haplogroups, A and D sensu [11], are present. It has been proposed that African haplogroup A originates from Southeast and/or East Asia [11]-[14]; and using phylogeographic information on the modern geographic distribution across Europe and Asia [10], the Indian subcontinent has been proposed as the initial center of origin for haplogroup D [11] [13] [14]. Other halogroups occur on the continent but at a very low frequency. Haplogroups B, C may have reached Africa following recent introductions of improved commercial chickens [11]. This suggestion is supported by the presence of identical or closely related haplotypes belonging to these haplogroups in European and commercial birds [13] [15] [16]. However, a more ancient and direct introduction of one or both of these haplogroups from their centers of origins in Asia also remains possible. The center of origin of haplogroup E, also observed at very low frequency on the Africa continent, remains speculative so far; it has only been observed in the north of the Equator in Sudan and Ethiopia [11].

From the five on the African continent haplogroups reported by Mwacharo et al. [4], two haplogroups, A and $\mathrm{D}$, dominate the continent. Haplogroup D is found in all the African countries studied and is the most common in all countries with the exception of Madagascar, Zimbabwe and eastern Kenya. It is the only haplogroup so far identified in West Africa, represented by Nigeria [17]. The next commonest haplogroup is A, which is absent from Uganda, Sudan, Nigeria and Ethiopia but is the commonest in Madagascar, Malawi, Zimbabwe and eastern Kenya. The other haplogroups are observed at very low frequencies in all studies, being present in only one or two birds.

This study completes information from phenotypes and biometric measurements of the domestic chickens from Chad [18] [19]. These previous studies examined the phenotypic diversity and took biometric measurements of three different populations (Hadjer-Lamis/Lac Chad, Guera and West Mayo-Kebbi). The findings of these studies suggest that these populations living in different geographic areas may represent different ecotypes with different phenotypic characteristics. We now address the issue of the maternal genetic origins of the chicken from Chad by examining sequence information from the mitochondrial DNA D-loop and by comparing our findings with sequences of reference from Asia. Our results are adding new information on the geographic distribution of chicken mitochondrial DNA haplogroups in Africa and more particularly in Central Africa. 


\section{Materials and Methods}

\subsection{Sample Collection and DNA Extraction}

Genomic DNA was extracted from air dried blood preserved on FTA classic cards (Whatman Biosciences), using the recommended manufacturer protocol, from 186 unrelated local village chickens from three geographical regions in Chad (Central Africa). The samples include 50 birds from the western region (Hadjer-Lamis/Lake Chad) representing population I (Chad I), 50 birds from the central region (Guera) representing population II (Chad II), 50 birds from Southern region (West Mayo-Kebbi) representing population III (Chad III) and 36 birds samples from various poultry markets of N'Djamena representing population IV (Chad IV). The DNA concentration and purity, A260/A280 ratio between 1.8 and 2.0, were assessed using a NanoDrop ${ }^{\circledR} 1000$ Spectrophotometer. Potential DNA degradation was visualized on 1\% agarose gel. Five samples (2 from Chad III and 3 from Chad IV) were removed from the analysis following poor DNA extraction yield and/or bad quality sequence information. To address the possible Asian origin of Chad village chicken, 9 Asian reference haplotypes were included in the analyses including the chicken mtDNA reference downloaded from the National Centre for Biotechnology Information (NCBI) (GenBank accession number AB098668).

\subsection{PCR Amplification and Sequencing}

Five hundred and forty nine base pairs of the mtDNA D-loop region were amplified using AV1F2 (5'-AGGACTACGGCTTGAAAAGC-3' [11] as the forward primer and H547

(5'-ATGTGCCTGACCGAGGAACCAG-3', accession number AB098668, Komiyama et al., 2003) as the reverse primer. PCR amplifications were carried out in a $20 \mu \mathrm{l}$ reaction volumes containing $40 \mathrm{ng}$ genomic DNA, $5 \times$ Phire reaction buffer (containing $1.5 \mathrm{mM} \mathrm{MgCl}_{2}$ at final reaction concentration), $200 \mu \mathrm{M}$ of each dNTP, 0.5 $\mu \mathrm{M}$ of each primer and $0.4 \mu \mathrm{l}$ of Phire Hot Start II DNA Polymerase (Thermo Scientific Ltd). The thermo-cycling conditions were Lid $\left(110^{\circ} \mathrm{C}\right)$, hot start $98^{\circ} \mathrm{C}(2 \mathrm{~min})$, denaturation $98^{\circ} \mathrm{C}(5 \mathrm{sec})$, annealing $63^{\circ} \mathrm{C}(10 \mathrm{sec})$, elongation $72^{\circ} \mathrm{C}(15 \mathrm{sec}), 35$ cycles and final extension step at $72^{\circ} \mathrm{C}$ for $1 \mathrm{~min}$ [20]-[22]. PCR products were purified using the NucleoSpin ${ }^{\circledR}$ Gel and PCR Clean-UP kit [23]. Purified products were sequenced using the AV1F2 (5'-AGGACTACGGCTTGAAAAGC-3') as the forward primer and H547

(5'-ATGTGCCTGACCGAGGAACCAG-3') as the reverse sequence primers.

\subsection{Sequence and Phylogenetic Analysis}

For each sample, two sequences were generated. The forward and reverse primers were trimmed and the two sequences were compared for consistency generating a 549 bp consensus sequence using CodonCode Aligner version 5.1.3 (www.codoncode.com/). The consensus sequence was aligned against the reference (GenBank accession number AB098668) [23] using Clustal $\times$ version 2.1 [25]. Subsequent analyses were restricted to the first 397 bp of the sequence which includes the hypervariable region (HV1) of the D-loop [17]. A NeighbourJoining (NJ) tree was constructed for all samples (sequences from Chad and reference sequences) with a 1000 boostrap replicates using MEGA version 6.0 [26]. The Median Joining (MJ) network was constructed using NETWORK 4.6.1.2 [27]. Sequence variation (nucleotide diversity, haplotype diversity and average number of nucleotide at each population) were calculated using DnaSP v5 [28].

\section{Results}

The analysis involved the first 397 bp of mtDNA D-loop sequences including the hypervariable region (HV1). A total of 20 haplotypes ( 3 from the population Chad I, 9 from Chad II, 10 from Chad III and 8 from Chad IV) defined by 25 polymorphic sites from 181 sequences was found (Figure 1). The individual haplotypes and haplogroups used in this study are defined by CD (Chad), H1 to H20 (Haplotype 1 to 20) while HapA, HapA01i03, HapA02, HapB, HapC, HapD, HapE, and HapF all represents different haplogroups from the Asian continent [11]. Haplotype and nucleotide diversities range from $(0.500 \pm 0.074-0.740 \pm 0.058)$ and $(0.0048 \pm 0.0013-$ $0.0074 \pm 0.0017$ ) across populations (Table 1), with Chad I and Chad II showing the lowest values for both. In particular despite the analysis of 50 birds only three haplotypes were observed in populations Chad while at the other extreme we do observe eight different haplotypes out of 33 birds from population Chad IV. 
1111222222222222333333333

4379113344566999011445699

$379272336617678605244716 \mathrm{~N}$

\begin{tabular}{|c|c|}
\hline Reference & АТАТАТССТТТСАТАСТСТААТТСТ \\
\hline CDH1 & ...GC..СССТ.С...TC.... \\
\hline CDH2 & ....GC.TCCСT.C...TC..... \\
\hline CDH3 & 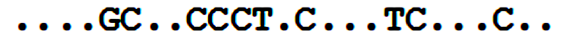 \\
\hline CDH4 & ..T.GC..СССТ.С...ТС..... \\
\hline CDH5 & ....GC..СССТGC...TC.. \\
\hline CDH6 & ...GC..CCCT.C..TC.G. \\
\hline CDH7 & ...GC..С.СT.C..TC... \\
\hline CDH8 & ...GC . .CCC . . . TC \\
\hline CDH9 & ...GC..CCCT.C.T.TC. \\
\hline CDH10 & .C..GCTTCCCT.C...TC. \\
\hline CDH11 & ... СGC . .СССТ.С...TC. \\
\hline CDH12 & ...GC.TCCCT.C...TCG \\
\hline CDH13 & ...GC..CCCT.C...TC. \\
\hline CDH14 & ....GC..CCCT.C..CTC. \\
\hline CDH15 & ...GC..CCCT.C...TC. \\
\hline CDH16 & T. . .GC . .CCCT.C...TC. \\
\hline CDH17 & ...GC..C.CT.C...TC. \\
\hline CDH18 & . . . .GC . .CCCT.CG. . TC. \\
\hline CDH19 & .C..GC.TCCCT.C...TC. \\
\hline $\mathrm{CDH} 20$ & ...GC . .CCCT.C...TC \\
\hline
\end{tabular}

Figure 1. Polymorphic sites of the 20 haplotypes observed in the mtDNA D-loop region from 181 village chicken sequences from Chad. The number of individuals within each haplotype is indicated by "N". The dots (.) indicate identity with reference sequence (GenBank accession number AB098668) [24].

Table 1. Sampling population, sample size, population genetic diversity measures, standard deviation (SD) for each population and Tajima's D ( $P$ value).

\begin{tabular}{cccccccc}
\hline Population & $\begin{array}{c}\text { Sample } \\
\text { size }\end{array}$ & $\begin{array}{c}\text { Haplotype } \\
\text { CDH1 } \\
\text { (number of } \\
\text { individuals } \\
\text { observed) }\end{array}$ & $\begin{array}{c}\text { Number of } \\
\text { haplotypes }\end{array}$ & $\begin{array}{c}\text { Haplotype } \\
\text { diversity } \\
\text { (SD) }\end{array}$ & $\begin{array}{c}\text { Nucleotide } \\
\text { diversity } \\
\text { per site (SD) }\end{array}$ & $\begin{array}{c}\text { Average } \\
\text { number of } \\
\text { nucleotide } \\
\text { differences (k) }\end{array}$ & $\begin{array}{c}\text { Tajima’s D } \\
(P \text { value })\end{array}$ \\
\hline${ }^{*}$ Chad I & 50 & 40 & 3 & $0.500(0.074)$ & $0.00484(0.00129)$ & 1.92344 & $-2.10352(P<0.05)$ \\
${ }^{*}$ Chad II & 50 & 37 & 9 & $0.583(0.076)$ & $0.00542(0.00129)$ & 2.15020 & $-2.32076(P<0.01)$ \\
${ }^{*}$ Chad III & 48 & 27 & 10 & $0.740(0.058)$ & $0.00656(0.00130)$ & 2.59962 & $-2.00892(P<0.05)$ \\
${ }^{*}$ Chad IV & 33 & 21 & 8 & $0.714(0.073)$ & $0.00744(0.00166)$ & 2.90128 & $-2.09414(P<0.05)$ \\
All populations & 181 & 127 & 20 & $0.541(0.044)$ & $0.00312(0.00049)$ & 1.21270 & $-2.37429(P<0.01)$ \\
\hline
\end{tabular}

${ }^{*}$ Chad I = Western region (Hadjer-Lamis/Lake Chad); Chad II = Central region (Guera); Chad III = Southern region (West Mayo-Kebbi); Chad IV = Various poultry markets of N'Djamena.

The Neighbour-joining tree and it bootstraps values support close relationships between all haplotypes with reference haplotype D belonging to the same group (Figure 2). In particular, all haplotypes identified in this study belong to haplogroup D (refer as haplogroup E in [10]), with one major CDH1 haplotype presents in 127 observations out of 181 (Figure 1). This haplotype (CDH1) is identical to our haplotype of reference HapD.

Haplotype network analysis (Figure 3 and Figure 4) further confirms the close relationship between all haplotypes. Figure 3 clearly illustrates that all these haplotypes belongs to a single expansion event centred on haplotype HapD (CDH1). This is also the case when the populations are analysed separately (Figure 4). 


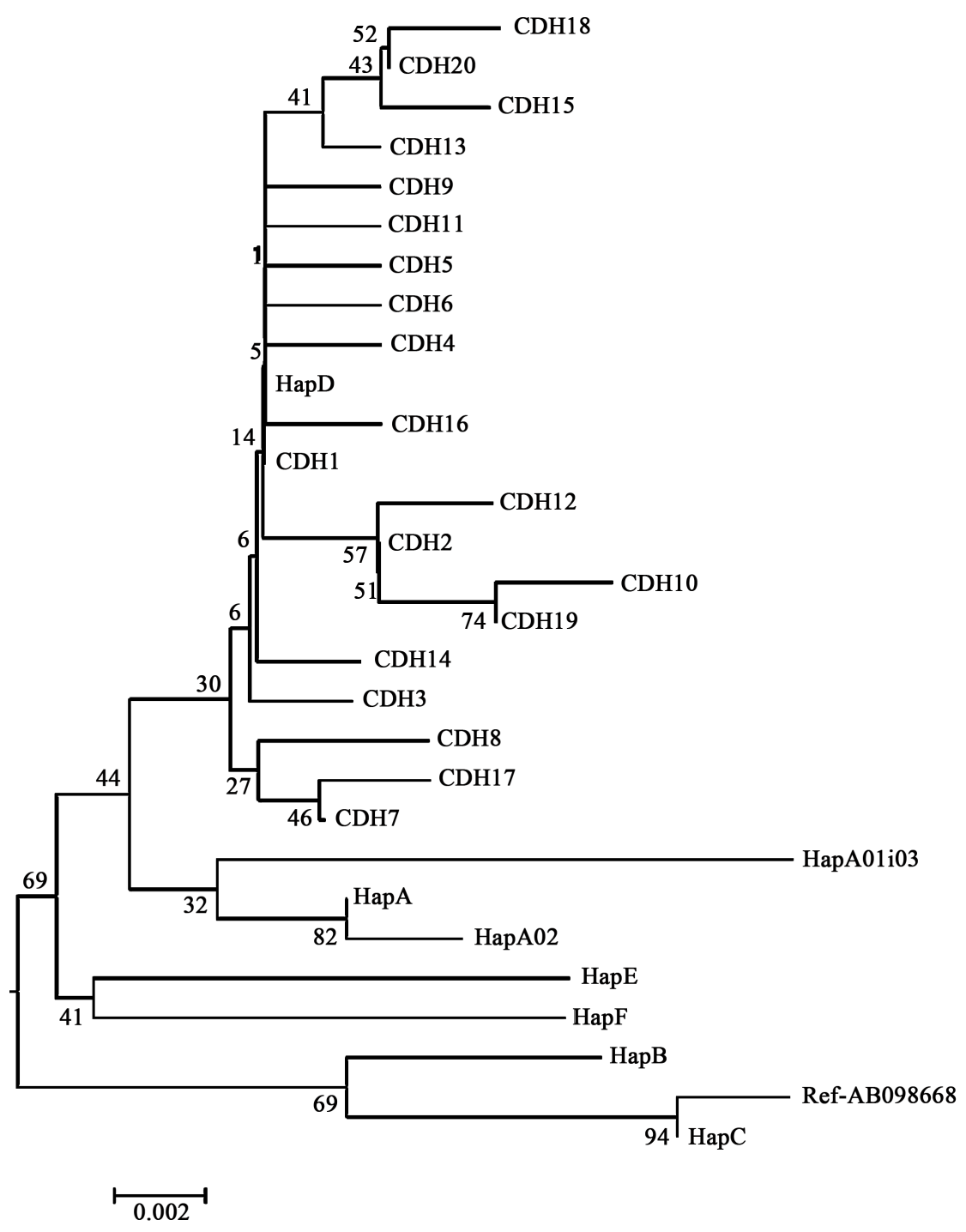

Figure 2. Neighbour-joining tree reconstructed from the 20 haplotypes identified in the 181 Chad village chicken sequences and the nine haplotypes of references using MEGA 6.0. The percent bootstrap value is represented by the numbers at the node after 1000 replication.

\section{Discussion}

The 20 haplotypes detected from a total of 25 polymorphic sites belong to a single haplogroup D (Figure 2). On the African continent two major haplogroups, A and D, have been reported previously [11]-[14]. Haplogroup D was found in all African countries studied and it is the commonest in all countries with the exception of Madagascar, Zimbabwe as well as the Eastern part of Kenya. Like in Chad, haplogroup D is the only haplogroup found so far in Nigeria [17], it also by far the commonest in Sudan and South Sudan (being refer as Clade IV in [29] in agreement with a possible common origin for the chicken from West and Central Africa. Haplogroup A was not observed in Chad. This haplogroup is absent from Uganda, Sudan, Nigeria, Sudan and South Sudan but is the commonest in Madagascar, Malawi, Zimbabwe and East Kenya. The absence of haplogroup A in Chad indicates that the likely introduction of chicken along the coast of East Africa did not contribute on the maternal side to the today genetic pool of the modern indigenous chicken from Chad. None of the rare haplogroups previously reported on the African continent (Mwacharo et al., 2013 [4]) were found in Chad.

The Indian subcontinent has been proposed as the initial center of origin for the haplogroup $\mathrm{D}$ found in Africa [11] [13] [14]. A possible Indian subcontinent origin of some African chickens is further supported by the 


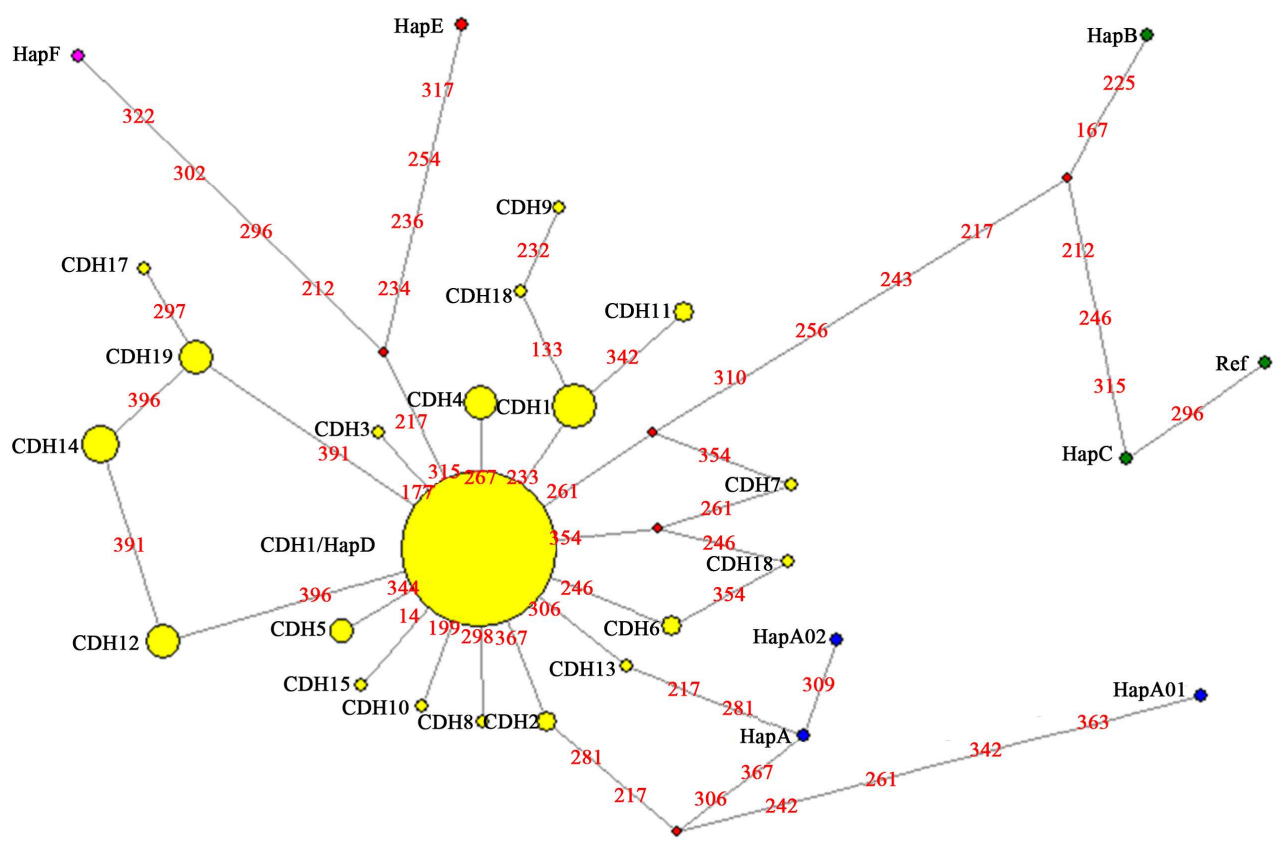

Figure 3. Median-joining network based on the mtDNA D-loop HV1 region for the 20 haplotypes of Chad indigenous chicken derived from 181 sequences and the nine reference haplotypes. Inferred ancestral haplotypes not sampled here are represented in red. The size of the circles is proportional to the frequency of the frequency of each haplotype. The positions of nucleotide mutations, compared to the reference sequence (GenBank accession number AB098668), correspond to the numbers between haplotype nodes.
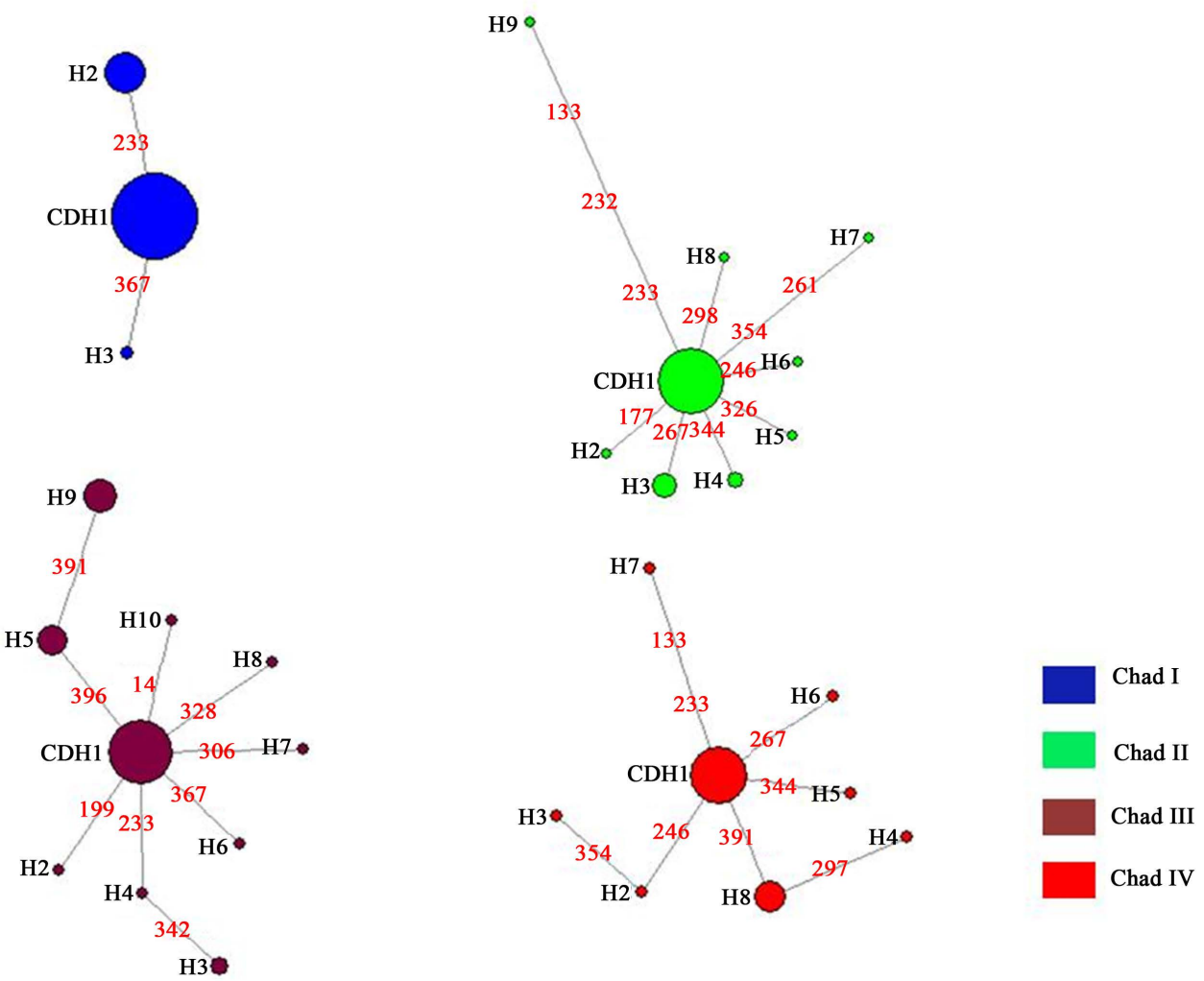

Figure 4. Median-joining network based on the mtDNA D-loop HV1 region for individual population. The number of individual in haplotype CDHI is referring in Table 1. 
commonly observed yellow skin phenotype across African village chickens [15] [18] [30]-[33]. This phenotype has recently been shown at the molecular level to be a legacy of successful introgression of the grey jungle fowl Gallus sonneratii, a yet to be domesticated Gallus species with restricted geographic range on the Indian subcontinent, into domestic chicken [34]. The yellow skin phenotype is also observed in Libya [35], and Egypt where haplogroup D has been shown to be present in indigenous chicken [36]. Together all these findings support that haplogroup D observed in local chicken from Chad originated from a single source, which is likely the Indian subcontinent. More specifically, we propose that the ancient maternal ancestor of indigenous chicken from Chad would have entered the country through trans-Saharan trading from Egypt or Sudan rather than through migration along the Sahelian belt from East Africa.

Within Chad, we do observe difference between populations (Table 1). The smallest number of haplotype was observed in Chad I while at the other end we do observe the largest number of haplotype in population Chad IV. In this later population, the birds were sampled at N'Djamena markets and it may be expected to find in the city birds that may have been imported from different parts of the countries or even neighbouring countries. This is further support by the large average nucleotide divergence between haplotypes observed in this region (Table 1). At the opposite we have found a very small number haplotypes in population CHD1 (regions of Hadjer-Lamis and Lake Chad) and CHD2 (region of Guera) two populations from the Sahel zone.

\section{Conclusion}

The aim of this study was to assess the possible origin of local chickens' populations in Chad and their genetic variation. A total of 20 haplotypes defined by 25 polymorphic sites from 181 sequences were identified. Only haplogroup D was observed. Haplogroup D is also the only haplogroup found in Sudan, Nigeria and now with the results of our study in Chad suggesting a common route and entry point of chicken to Central and West Africa involving trans-Saharan trading from Egypt or Sudan. Combined with phenotypic information, these results provide important baselines information to guide poultry improvement programs aiming to conserve and utilise indigenous animal genetic resources from Chad.

\section{Acknowledgements}

This work was financially supported by a National Fund (CONFOFOR) for Scientific Research and Training of Trainers (Chad). This article was produced as part of ongoing effort aiming to better characterize the local chickens populations of Chad for conservation, improvement, sustainable utilization purposes.

\section{References}

[1] FAOSTAT (2012) FAO Statistical Yearbook 2012. FAO, Rome. http://faostat.fao.org/

[2] Garrigus, W.P. (2007) Poultry Farming. Encyclopaedia Britannica. http://www.britannica.com/eb/article-9111040

[3] Crawford, R.D. (1990) Origin and History of Poultry Species. In: Crawford. R.D., Ed., Poultry Breeding and Genetics. Elsevier, Amsterdam.

[4] Mwacharo, J.M., Bjørnstad, G., Han, J.L. and Hanotte, O. (2013) The History of African Village Chickens: An Archaeological and Molecular Perspective. African Archaeological Review, Published Online.

[5] MacDonald, K.C. and Edwards, D.N. (1993) Chicken in Africa: The Importance of Qasr Ibrim. Antiquity, 67, 584-590.

[6] Haller, A. (1954) Die Gräber und Grüfte von Assur. Berlin, Germany.

[7] Rivallain, J. and Van Neer, W. (1983) Inventory of the Archaeological and Faunal Material at Koyom, South Chad. Anthropologie, Masson editor Nr. 88, 441-448.

[8] Guèye, E.F. (1998) Village Egg and Fowl Meat Production in Africa. World's Poultry Science Journal, 54, 73-86. http://dx.doi.org/10.1079/WPS19980007

[9] Guèye, E.F. and Bessei, W. (1995) La poule locale sénégalaise dans le contexte villageois et les possibilités d'amélioration de ses performances. In: Sustainable Rural Poultry Production. Proceedings of an International Workshop, 13-16 June 1995, the International Livestock Research Institute, Addis Ababa, Ethiopia, 112-123.

[10] Liu, Y.P., Wu, G.S., Yao, Y.G., Miao, Y.W., Luikart, G., Baig, M., Beja-Pereira, A., Ding, Z.L., Alanichamy, M.G. and Zhang, Y.P. (2006) Multiple Maternal Origins of Chickens: Out of the Asian Jungles. Molecular Phylogenetics and Evolution, 38, 12-19. http://dx.doi.org/10.1016/j.ympev.2005.09.014

[11] Mwacharo, J.M., Bjørnstad, G., Mobegi, V., Nomura, K., Hanada, H., Amano, T., Jianlin, H. and Hanotte, O. (2011) 
Mitochondrial DNA Reveals Multiple Introductions of Domestic Chicken in East Africa. Molecular Phylogenetics and Evolution, 58, 374-382. http://dx.doi.org/10.1016/j.ympev.2010.11.027

[12] Razafindraibe, H., Mobegi, V.A., Ommeh, S.C., Rakotondravao, G., Bjørnstad, G., Hanotte, O. and Jianlin, H. (2008) Mitochondrial DNA Origin of Indigenous Malagasy Chicken. Annals of the New York Academy of Sciences, 1149, 7779. http://dx.doi.org/10.1196/annals.1428.047

[13] Muchadeyi, F.C., Eding, H., Simianer, H., Wollny, C.B.A., Groeneveld, E. and Weigend, S. (2008) Mitochondrial DNA D-Loop Sequences Suggest a Southeast Asian and Indian Origin of Zimbabwean Village Chicken. Animal Genetics, 39, 615-622. http://dx.doi.org/10.1111/j.1365-2052.2008.01785.x

[14] Mtileni, B.J., Muchadeyi, F.C., Maiwashe, A., Chimonyo, M., Groeneveld, E., Weigend, S. and Dzama, K. (2011) Diversity and Origin of South African Chicken. Poultry Science, 90, 2189-2194. http://dx.doi.org/10.3382/ps.2011-01505

[15] Dana, N., Megens, H.J., Crooijmans, R.P.M.A., Hanotte, O., Mwacharo, J.M., Groenen, M.A. and Van Arendonk, J.A. (2010) East Asian Contributions to Dutch Traditional and Western Commercial Chickens Inferred from mtDNA Analysis. Animal Genetics, 42, 125-133. http://dx.doi.org/10.1111/j.1365-2052.2010.02134.x

[16] Ceccobelli, S., Di Lorenzo, P., Hovirag, L., Monteagudo, L., Tejedor, M.T. and Castellini, C. (2015) Genetic Diversity and Phylogeographic Structure of Sixteen Mediterranean Chicken Breeds Assessed with Microsatellites and Mitochondrial DNA. Livestock Science, 175, 27-36. http://dx.doi.org/10.1016/j.livsci.2015.03.003

[17] Adebambo, A.O., Mobegi, V., Mwacharo, A., Oladejo, J.M., Adewale, B.M., Ilori, R.A., Makanjuola, L.O., Afolayan, B.O., Bjørnstad, O., Jianlin, H. and Hanotte, O. (2010) Lack of Phylogeographic Structure in Nigerian Village Chickens Revealed by Mitochondrial DNA D-Loop Sequence Analysis. International Journal of Poultry Science, 9, 503-507. http://www.pjbs.org/ijps/ab1670.htm http://dx.doi.org/10.3923/ijps.2010.503.507

[18] Hassaballah, K., Zeuh, V. and Sembene, M. (2014) Phenotypic Diversity of Local Chickens (Gallus domesticus) in Three Ecological Zones of Chad. International Journal of Current Research in Biosciences and Plant Biology, 1, 1-8.

[19] Hassaballah, K., Zeuh, V., Mopate, L.Y. and Sembene, M. (2015) Caractérisation morpho-biométrique des poules (Gallus gallus) locales dans trois zones agro-écologiques du Tchad. Livestock Research for Rural Development, 27, Article No.: 53. http://www.lrrd.org/lrrd27/3/hass27053.html

[20] Chester, N. and Marshak, D.R. (1993) Dimethyl Sulfoxide-Mediated Primer $T_{\mathrm{m}}$ Reduction: A Method for Analyzing the Role of Renaturation Temperature in the Polymerase Chain Reaction. Analytical Biochemistry, 209, $284-290$. http://dx.doi.org/10.1006/abio.1993.1121

[21] Nord, K., Gunneriusson, E., Ringdahl, J., Ståhl, S., Uhlén, M. and Nygren, P.A. (1997) Binding Proteins Selected from Combinatorial Libraries of an $\alpha$-Helical Bacterial Receptor Domain. Nature Biotechnology, 15, 772-777. http://dx.doi.org/10.1038/nbt0897-772

[22] Wikman, M., Steffen, A.C., Gunneriusson, E., Tolmachev, V., Adams, G.P., Carlsson, J. and Ståhl, S. (2004) Selection and Characterization of HER2/Neu-Binding Affibody Ligands. Protein Engineering, 17, 455-462. http://dx.doi.org/10.1093/protein/gzh053

[23] Vogelstein, B. and Gillespie, D. (1979) Preparative and Analytical Purification of DNA from Agarose. Proceedings of the National Academy of Sciences of the United States of America, 76, 615-619. http://dx.doi.org/10.1073/pnas.76.2.615

[24] Komiyama, T., Ikeo, K. and Gojobori, T. (2003) Where Is the Origin of the Japanese Gamecocks? Gene, 317, $195-202$. http://dx.doi.org/10.1016/S0378-1119(03)00703-0

[25] Thompson, J.D., Gibson, T.J., Plewniak, F., Jeanmougin, F. and Higgins, D.G. (1997) The ClustalX Windows Interface: Flexible Strategies for Multiple Sequence Alignment Aided by Quality Analysis Tools. Nucleic Acids Research, 25, 4876-4882. http://dx.doi.org/10.1093/nar/25.24.4876

[26] Tamura, K., Stecher, G., Peterson, D., Filipski, A. and Kumar, S. (2013) MEGA6: Molecular Evolutionary Genetics Analysis Version 6.0. Molecular Phylogenetics and Evolution, 30, 2725-2729. http://dx.doi.org/10.1093/molbev/mst197

[27] Bandelt, H.J., Forster, P. and Röhl, A. (1999) Median-Joining Networks for Inferring Intraspecific Phylogenies. Molecular Phylogenetics and Evolution, 16, 37-48. http://dx.doi.org/10.1093/oxfordjournals.molbev.a026036

[28] Librado, P. and Rozas, J. (2009) DnaSP v5: A Software for Comprehensive Analysis of DNA Polymorphic Data. Bioinformatics, 25, 1451-1452. http://dx.doi.org/10.1093/bioinformatics/btp187

[29] Wani, C.E., Yousif, I.A., Ibrahim, M.E. and Musa, H.H. (2014) Molecular Characterization of Sudanese and Southern Sudanese Chicken Breeds Using mtDNA D-Loop. Genetics Research, 2014, Article ID: 928420. http://dx.doi.org/10.1155/2014/928420

[30] FAO (2009) Characterization of Domestic Chicken and Duck Production Systems in Egypt. Prepared by Haitham H., Mohamed Kosba and Olaf Thieme. AHL-Promoting Strategies for Prevention and Control of HPAI, Rome. 
[31] Youssao, I.A.K., Tobada, P.C., Koutinhouin, B.G., Dahouda, M., Idrissou, N.D., Bonou, G.A., Tougan, U.P., Ahounou, S., Yapi-Gnaoré, V., Kayang, B., Rognon, X. and Tixier-Boichard, M. (2010) Phenotypic Characterisation and Molecular Polymorphism of Indigenous Poultry Populations of the Species Gallus gallus of Savannah and Forest Ecotypes of Benin. African Journal of Biotechnology, 9, 369-381. http://www.academicjournals.org/AJB

[32] Daikwo, I.S., Okpe, A.A. and Ocheja, J.O. (2011) Phenotypic Characterization of Local Chickens in Dekina. International Journal of Poultry Science, 10, 444-447. http://www.pjbs.org/ijps/ab1905.htm http://dx.doi.org/10.3923/ijps.2011.444.447

[33] Melesse, A. and Negesse, T. (2011) Phenotypic and Morphological Characterization of Indigenous Chicken Populations in Southern Region of Ethiopia. Animal Genetic Resources Information, 49, 19-31. http://dx.doi.org/10.1017/S2078633611000099

[34] Eriksson, J., Larson, G., Gunnarsson, U., Bed’hom, B., Tixier-Boichard, M., Strömstedt, L., Wright, D., Jungerius, A., Vereijken, A., Randi, E., Jensen, P. and Andersson, L. (2008) Identification of the Yellow Skin Gene Reveals a Hybrid Origin of the Domestic Chicken. PLoS Genetics, 4, e1000010. http://dx.doi.org/10.1371/journal.pgen.1000010

[35] El-Safty, S.A. (2012) Determination of Some Quantitative and Qualitative Traits in Libyan Native Fowls. Egypt. Poultry Science, 32, 247-258.

[36] Elkhaiat, I., Kawabe, K., Saleh, K., Younis, H., Nofal, R., Masuda, S. and Shimogori, T. (2014) Genetic Diversity of Egyptian Native Chickens Using mtDNA D-Loop Region. Journal of Poultry Science, 51, 359-363. http://dx.doi.org/10.2141/jpsa.0130232 